Agata Borek

Wrocław

\title{
Wizerunek Polski i polskich marek w oczach obcokrajowców mieszkajacych w Polsce
}

Zdaniem psychologów ludzie, mając przed sobą zadania, które wymagają wzmożonego wysiłku, nieświadomie postrzegają je jako mało zachęcające. Takie podejście skłania do szukania rozwiązań łatwiejszych, co zapewne można odnieść także do procesu podejmowania decyzji zakupowych. Konsumenci chcą dokonywać świadomych wyborów, ale często brakuje im czasu i cierpliwości na precyzyjne ustalenie, czy produkt, który trzymają w ręku, jest wysokiej jakości. Czasem podjęcie decyzji ułatwia informacja o kraju pochodzenia towaru. Kupujący nie muszą wówczas znać produktu, aby wiedzieć, że jest on dobry. Wystarczy, że państwo, z którego pochodzi produkt, cieszy się dobrą reputacją na arenie międzynarodowej. Tak jest na przykład w wypadku Niemiec, kojarzonych z wysokiej klasy autami, czy Japonii, przywołującej na myśl najbardziej zaawansowane technologicznie produkty.

Polska od lat pracuje nad swoim wizerunkiem. Na jego kształt niekorzystnie wpływają skomplikowana historia i funkcjonujące w świadomości społecznej stereotypy. Młodzi obcokrajowcy mieszkający w Polsce to nowa i nieobciążona tymi dwoma elementami grupa, interesująca tym bardziej, że może zderzyć z sobą wyobrażenia towarzyszące im jeszcze przed odwiedzeniem Polski z tymi, które pojawiły się już po przyjeździe.

Niektóre spośród polskich marek są rozpoznawalne na całym świecie, z czego często nie zdają sobie sprawy sami Polacy. Big Star, Reserved, Inglot, Gino Rossi, Yes - to tylko niektóre z nich. I chociaż nie podlega dyskusji, że pojedyncze marki nie zmienią postrzegania całego kraju i wywodzących się z niego pozostałych pro- 
duktów, to jednak posiłkując się popularnymi brandami, można w ciekawy sposób zbadać postrzeganie Polski.

Podczas próby weryfikacji aktualnej kondycji naszej marki narodowej autorka badań postawiła pytanie, czy kraj pochodzenia respondentów może mieć wpływ na udzielane odpowiedzi. Pochylono się również nad interpretacją ewentualnych różnic w wypowiedziach mieszkańców półkuli wschodniej i zachodniej.

\section{Metodologia przeprowadzonych badań i grupa badanych}

Celem przeprowadzonego badania było uzyskanie odpowiedzi na 3 kluczowe pytania:

- Jaki jest wizerunek Polski w oczach obcokrajowców mieszkających na jej terytorium?

- Co imigranci mieszkający w Polsce sądzą na temat marek polskiego pochodzenia?

- Czy pochodzenie respondentów ma wpływ na udzielane przez nich odpowiedzi, a jeśli tak, to z czego to wynika?

Ze względu na wielowątkowość podejmowanego tematu uznano, że najlepszą metodą zbierania danych będą pogłębione wywiady indywidualne $\mathrm{z}$ wykorzystaniem technik projekcyjnych.

Respondenci zostali wybrani według trzech kryteriów:

— wiek - do 35 lat,

— kraj pochodzenia — część badanych z Zachodu, część ze Wschodu,

- wykształcenie - wyższe.

Grupę badawczą stanowiło osiem osób. Byli to ludzie młodzi — kobiety i mężczyźni między 21. a 34. rokiem życia, obcokrajowcy od średnio półtora roku mieszkający i pracujący w Polsce, posiadający wykształcenie wyższe. Wybór respondentów pod kątem wieku i wykształcenia nie był przypadkowy. Przedstawiciele pokolenia Y mają dużo większą świadomość marek dzięki mediom społecznościowym. Co więcej, sama koncepcja brandingu narodowego rozkwitła w Polsce dopiero z początkiem XXI wieku. Wtedy rząd podjął pierwsze działania mające na celu poprawę wizerunku naszego kraju1. W związku z tym osoby starsze i mniej wykształcone mogą nie być wystarczająco dobrze zaznajomione $\mathrm{z}$ samą ideą budowania marki narodowej.

Jeśli chodzi o kraj pochodzenia respondentów, trzy z ośmiu zbadanych osób dorastały w państwach byłego bloku wschodniego, reszta zaś - odpowiednio - w zachodniej Azji, Europie Zachodniej, Europie Północnej, Ameryce Północnej i Ameryce Południowej. Taki dobór próby pozwolił nie tylko w sposób ogólny sprawdzić, jaki wizerunek Polski i polskich marek rysuje się w oczach obcokrajowców mieszkających

1 M. Raftowicz-Filipkiewicz, Efekty brandingu narodowego w Polsce, http://www.bibliotekacyfrowa. pl/Content/27793/07_Magdalena_Raftowicz_Filipkiewicz.pdf (dostęp: 27 lipca 2017). 
w Polsce, ale także ustalić, czy część świata, z której pochodzą badani, może wpływać na ich ocenę.

Uzyskane w badaniu dane analizowano poprzez kategoryzację. Dzięki temu można było wyodrębnić najważniejsze zagadnienia oraz opinie każdego z rozmówców, a następnie zestawić je z sobą. Na końcu sprawdzono, czy odpowiedzi respondentów w obrębie tych samych zagadnień były podobne czy rozbieżne. $Z$ wyników wyciągano później wnioski oraz szukano zależności pomiędzy wypowiedziami badanych a krajem ich pochodzenia.

\section{Kształtowanie polskiej marki narodowej}

Trudno jednoznacznie określić, jaki wizerunek Polski funkcjonuje obecnie na arenie międzynarodowej. Wiele zależy od podmiotu badającego obraz naszego państwa, próby oraz metodologii. Opierając się na fragmentarycznych wynikach badań prowadzonych na przestrzeni kilkunastu lat, można jednak wyciągnąć pewne wnioski.

W latach 1998-2001 prowadzono projekt — prawdopodobnie pierwszy dotyczący wizerunku Polski i Polaków w krajach europejskich — w którym badano postrzeganie Polski w Austrii, Szwecji, Niemczech, Wielkiej Brytanii, Hiszpanii, Francji i na Ukrainie. Podmiotem odpowiedzialnym za opracowanie struktury projektu badawczego był Instytut Spraw Publicznych. Wyczerpująca publikacja Leny Kolarskiej-Bobińskiej, Obraz Polski i Polaków w Europie, przedstawiająca wyniki tego badania, pozwala stwierdzić kilka istotnych rzeczy ${ }^{2}$. Obalenie komunizmu i przełomowy rok 1989 w żaden sposób nie wpłynęły na postrzeganie naszego kraju przez Unię Europejską. Wśród członków Wspólnoty nadal panowała niewiedza na temat Polski. Była ona dla nich krajem zacofanym, skorumpowanym, o konserwatywnych poglądach i niskim poziomie gospodarczym, stojącym w sprzeczności z unijnymi standardami.

W roku 2004, tuż przed akcesją Polski do Unii Europejskiej, zespół Waly’ego Olinsa prowadził badanie w związku z projektem Marka dla Polski. Jego wyniki są zbliżone do tych, przedstawionych powyżej. Dla mieszkańców USA, Hiszpanii, Rosji, Niemiec, Wielkiej Brytanii i Węgier, z którymi przeprowadzono wywiady pogłębione, dominującymi skojarzeniami z Polską były: papież Jan Paweł II, druga wojna światowa, Solidarność, religijność, Fryderyk Chopin, zanieczyszczone środowisko oraz mało rozwinięte rolnictwo. Ten negatywny obraz Polski był widoczny także w światowych mediach, które nie szczędziły krytycznych uwag pod adresem Polski, stojącej u progu członkostwa w UE.

Najistotniejszym efektem pracy zespołu Olinsa było sformułowanie myśli przewodniej dla polskiej marki narodowej. Określono ją mianem creative tension, co miało odzwierciedlać sprzeczną naturę naszego kraju. Chodziło o zbiór antagonistycznych

2 L. Kolarska-Bobińska, Obraz Polski i Polaków w Europie, Warszawa 2003. 
cech przypisywanych Polsce i składających się na jej osobowość, na przykład bycie częścią Zachodu i jednoczesne zrozumienie Wschodu.

Kolejnym badaniem, na które należy się powołać, opisując wizerunek Polski na przestrzeni lat, jest Anholt - Gfk Roper Nation Brand Index (NBI). Dzięki tej metodologii, wykorzystującej sześciokąt kanałów narodowej komunikacji, bada się kondycję 50 marek narodowych. Kiedy w 2005 roku ranking Simona Anholta obejmował 35 krajów, Polska uplasowała się na trzydziestym miejscu, pokonując jedynie Turcję, Malezję, RPA, Indonezję i Estonię. W 2009 roku Polska zajęła po raz kolejny trzydzieste miejsce, przy czym ranking obejmował już 50 państw. W jednym i drugim okresie Polska uzyskała najlepsze wyniki w obszarze jakości rządów, ludzi i eksportu i najgorsze w kategorii turystyki i kultury, co wywołało duże zaskoczenie, ponieważ Polacy do dziś uważają je za swoje najmocniejsze strony.

Pozytywnym akcentem w kwestii turystyki są wnioski z raportu Future Brands. Samo badanie zostało przeprowadzone na podróżnikach, ekspertach w dziedzinie turystyki, analitykach i pisarzach. W 2007 roku nasz kraj zajął ósme miejsce w rankingu obejmującym państwa, które do 2012 miały szansę stać się popularnymi kierunkami turystycznymi.

W 2006 roku na zlecenie Ministerstwa Spraw Zagranicznych przeprowadzono badanie reputacji i wizerunku Polski. Próbę badanych stanowiły osoby dorosłe z Rosji, Stanów Zjednoczonych i Wielkiej Brytanii. W każdym z tych krajów przebadano około 1000 osób. Wyniki pokazują, że poziom wiedzy o Polsce był w tym czasie równie niski, co przed naszą akcesją do UE. Respondenci, pytani o opinię na temat polskich produktów i marek, nie potrafili wskazać konkretów. Pozytywne nastawienie do Polski wykazało 38\% Rosjan, 26\% mieszkańców Wielkiej Brytanii i jedynie 19\% Amerykanów, z których ponad połowa w ogóle nie wiedziała, co myśleć o Polsce. Skojarzenia z Polską były bardzo niejednoznaczne. Z ust Brytyjczyków padały hasła: zimna pogoda, śnieg, imigranci i druga wojna światowa. Rosjanie zwracali uwagę na kosmetyki, bliskie sąsiedztwo i słowiańską kulturę. Dużo lepiej prezentował się w tamtym czasie wizerunek typowego Polaka. Zarówno większość amerykańska, jak i brytyjska określiła Polaków mianem pracowitych, godnych zaufania, wykształconych i zorganizowanych ${ }^{3}$.

Pod koniec 2011 roku Fundacja Best Place Europejskiego Instytutu Marketingu Miejsc przeprowadziła badanie dotyczące wizerunku i promocji Polski. Grupę badawczą stanowiło czternastu światowej sławy ekspertów w dziedzinie nation brandingu. Wśród pierwszych skojarzeń z Polską najczęściej pojawiającymi się odpowiedziami były kolejno: Jan Paweł II, Europa Wschodnia, koniec komunizmu, rodzina, wódka, zakupy, piłka nożna, zimno. Prawie co trzeci badany nie miał żadnych skojarzeń z naszym krajem. Ekspertów zapytano także o najbardziej charakterystyczne dla Polski marki. Jak się okazało, rozpoznawalność naszych produktów za granicą była bardzo

3 W. Olins, A Brand for Poland - Advancing Poland's National Identity, Warszawa 2004. 
mała. Co piąty respondent potrafił wymienić trzy produkty polskiego pochodzenia. Na pierwszym miejscu uplasowały się wódka, LOT, Żubrówka, Star Petrol Station, tanie artykuły spożywcze, Wedel i PKP. Jak podaje raport Eye on Poland - promocja $i$ wizerunek Polski w oczach międzynarodowych ekspertów marketingu miejsc, „za markowy wyróżnik naszego kraju eksperci Best Place uznali również "taniość« w kategoriach - materiałów budowlanych, artykułów spożywczych i ubrań"

Podsumowując odpowiedzi ekspertów, należy stwierdzić, że wizerunek Polski w tamtym czasie był niejednoznaczny. Niemniej jednak większość skojarzeń związanych z naszym krajem można określić mianem pozytywnych. Dowody na to są widoczne także w innych źródłach, z których wynika, że Polska w oczach obcokrajowców pozycjonowała się jako kraj z potencjałem, o którym nie można było powiedzieć niczego konkretnego 5 .

W 2011 roku przeprowadzono wstępną analizę postrzegania Polski i jej gospodarki na rynku niemieckim, włoskim, rosyjskim, francuskim, niderlandzkim, czeskim, amerykańskim, chińskim i ukraińskim. W 2015 roku powtórzono badanie i porównano je $\mathrm{z}$ wynikami sprzed czterech lat. Pozwoliło to na ocenę zmian w wizerunku Polski. I tak w 2015 roku Polskę zdecydowanie częściej kojarzono ze wzrostem gospodarczym i poprawiającą się jakością polskich produktów. Respondenci zwrócili uwagę na to, że Polska wyróżnia się na tle swoich wschodnich sąsiadów. Firmy zagraniczne wykazały się też znajomością coraz to większej liczby polskich marek, szczególnie produktów spożywczych, kosmetycznych i AGD. W końcu zauważono też wyraźną tendencję do lepszej oceny naszego kraju przez ludzi, którzy mieli okazję go odwiedzić6.

Z analizy powyższych badań wynika, że percepcja polskiej marki narodowej, choć powoli, poprawiała się na przestrzeni tych kilkunastu lat.

\section{Wizerunek Polski w oczach badanych obcokrajowców}

Jednym z głównych celów badania było określenie wizerunku Polski w oczach zamieszkujących ją obcokrajowców. W pierwszej kolejności zapytano respondentów o konotacje ze słowem „Polska” z okresu, gdy nie mieszkali jeszcze w Polsce, oraz $\mathrm{o}$ aktualne skojarzenia $\mathrm{z}$ tym słowem.

${ }^{4}$ http://bestplaceinstytut.org/www/wp-content/uploads/2012/02/Eye-on-Poland-raport-w-pol.-wersji.pdf (dostęp: 2 maja 2017).

5 W. Smoczyński, Polska: kraj bez twarzy, http://www.polityka.pl/kraj/analizy/295379,1,nasz-wizerunek-za-granica.read (dostęp: 2 maja 2017).

${ }^{6}$ https://www.mr.gov.pl/media/15472/7_Broszura_badania_wizerunkowe_ex-post.pdf (dostęp: 2 maja 2017).

Dziennikarstwo i Media 9, 2018

(C) for this edition by CNS 
Respondenci przed przyjazdem do Polski albo w ogóle nie mieli zdania na jej temat, albo kojarzyli ją ze względu na ważne fakty historyczne. Część z nich odbierała Polskę negatywnie - jako kraj tanich pracowników fizycznych.

Skojarzenia respondentów ze słowem „Polska” po przyjeździe do kraju uległy znacznej poprawie. Badani w większości wskazywali na pozytywne konotacje. Jedynym negatywnym skojarzeniem wymienianym zarówno w odniesieniu do czasu przed przyjazdem do Polski, jak i do czasu pobytu była „tania siła robocza” — odpowiedź ta padła dwa razy. Wniosek z tego, że wizerunek Polski nie jest ani silny, ani słaby, a raczej mieszany, bliżej mu jednak do korzystnych asocjacji. Długi czas reakcji badanych wskazuje na to, że trudno znaleźć jedno trafne skojarzenie z Polską — nawet w sytuacji, gdy od pewnego czasu jest się jej mieszkańcem.

W dalszej części badań wizerunku Polski w oczach obcokrajowców wykorzystano jedną z technik projekcyjnych. Respondentów poproszono o opisanie Polski jako człowieka. Personalizacja miała na celu zbadać, jak obcokrajowcy postrzegają Polaków, jakie cechy charakteru i osobowości im przypisują oraz jaki mają do nich stosunek.

Odpowiedzi respondentów nie były jednolite, ale po głębszej analizie udało się z nich wyodrębnić cztery odmienne typy „osobowości” Polski. Wskazane personifikacje to: Oszczędny; XYZ; Matka Polka; Millenials.

Wizerunek Polski wyłaniający się z uzyskanych personifikacji jest rozmyty i niejednoznaczny. Najwięcej, bo aż połowa badanych, portretuje Polskę jako człowieka oszczędnego, ambitnego i niezwykle pracowitego, dla którego rodzina stanowi najwyższą wartość w życiu. Wszystkie opisy łączy wiele cech konserwatywnych, charakterystycznych, jak się okazuje, dla Polski. Należy zwrócić uwagę na fakt, że trzy z czterech opisów są nacechowane pozytywnie lub neutralne - zarówno „Oszczędnemu”, „Millenialsowi”, jak i „Matce Polce” nie towarzyszą bowiem określenia negatywne. Wyjątek stanowi tu uwaga, która pojawiła się przy opisie „Millenialsa”, wskazująca na negatywny stosunek Polaków do obcych, ludzi innego koloru skóry, rasy czy orientacji seksualnej. Tylko jeden opis, na który wskazało dwoje badanych, ma charakter w pełni pejoratywny. Cechy przypisane „XYZ” są podobne do tych, opisujących stereotypowego Polaka jako człowieka leniwego i nadużywającego alkoholu.

\section{Polskie marki z perspektywy imigrantów mieszkających w Polsce}

W kolejnym etapie badania skupiono się na wizerunku polskich marek. Ta część pracy miała na celu sprawdzenie, jaki stosunek do brandów polskiego pochodzenia mają respondenci oraz jak ów stosunek ma się do wcześniejszej oceny Polski jako kraju. Najpierw przeanalizowano znajomość polskich marek u obcokrajowców, a następnie opinie na ich temat.

$\mathrm{Z}$ analizy odpowiedzi badanych wynika, że aż $88 \%$ z nich potrafi wskazać przynajmniej jedną polską markę. I choć wymieniane brandy były bardzo zróżnicowane, 
udało się je pogrupować według trzech kategorii: alkohol, ubrania oraz inne. Najwięcej, bo aż 42\% wszystkich odpowiedzi, wpisuje się w kategorię „alkohol”. Nieco mniej, bo $32 \%$ odpowiedzi, w kategorię „ubrania”, a 26\% w kategorię „inne”.

Najczęściej padającymi odpowiedziami na pytanie o polskie marki były: Reserved, Żubrówka oraz Tyskie. Sama kategoria „ubrania” pomieściła marki należące do popularnego w Polsce i poza jej granicami koncernu LPP (Reserved, Cropp, Mohito i House). Grupa „inne” objęła pojedyncze marki pochodzące z różnych segmentów rynku: kosmetycznego (Ziaja), obuwniczego (Aldo), cukierniczego (Wedel), samolotowego (LOT) oraz elektrycznego (Saturn — choć w istocie jest to niemiecka sieć).

\section{Ocena polskich marek}

Chcąc uzyskać informacje, jak obcokrajowcy mieszkający w Polsce oceniają jej produkty, zaproponowano badanym cztery czynniki — design, ekologia, jakość i cena a następnie poproszono o odniesienie każdego z nich do polskich marek. Pytanie skonstruowano za pomocą czterostopniowej skali Likerta. Celem było sprawdzenie, czy polskie marki są według respondentów tanie — raczej tanie - raczej drogie drogie, niskiej jakości — raczej niskiej jakości — raczej wysokiej jakości — wysokiej jakości oraz czy, a jeśli tak, to w jakim stopniu polscy producenci dbają o design i ekologiczność wypuszczanych marek.

Analiza uzyskanych odpowiedzi pozwala wyciągnąć kilka istotnych wniosków. Obcokrajowcy mieszkający w Polsce twierdzą, że polskie marki są z reguły tanie. Może to wynikać z faktu, że wielkość gospodarki oraz siła nabywcza Polski są mniejsze od tych, cechujących kraje pochodzenia respondentów. Jakość polskich produktów została oceniona pozytywnie przez badanych, w przeciwieństwie do designu i ekologiczności marek, przy czym rozbieżność odpowiedzi przy czynniku „design” świadczy o tym, że jest to kwestia sporna i niejednoznaczna dla obcokrajowców.

Zgłębiając temat wizerunku polskich marek, badanym zaproponowano kolejną technikę projekcyjną — „pudełko”. Uzyskane odpowiedzi udało się przyporządkować do dwóch kategorii: „rzeczy” i „cechy”. Kategorię „rzeczy” reprezentują: alkohol, jedzenie, transport, agroturystyka (w kolejności wskazującej na liczbę wskazań od najczęstszej); kategorię „,cechy” reprezentują: taniość, oryginalne, dziwne, staroświeckość, interesujące, praktyczne, wytrzymałe, dobre produkty za rozsądną cenę.

Podane odpowiedzi nie sugerują jednoznacznie, czy polskie marki kojarzą się obcokrajowcom pozytywnie czy negatywnie. Można przypuszczać, iż hasło „polska marka" nie niesie z sobą żadnych konkretnych skojarzeń.

Ostatnia, a zarazem najbardziej rozbudowana część badania, odnosiła się do oceny polskich marek przez obcokrajowców mieszkających w naszym kraju. W tym celu wykorzystano pięć popularnych marek - Reserved, Zara, Biedronka, Inglot, CCC. 
Na wstępie zapytano respondentów, czy znają wszystkie podane marki. Dalej poproszono ich o wskazanie, która z podanych marek i dlaczego jest według nich polska, a która zagraniczna - w tym celu zastosowano czterostopniową skalę Likerta (raczej polska - polska - raczej zagraniczna - zdecydowanie zagraniczna). Celem badania było skłonienie badanych do sformułowania argumentów, dlaczego dane marki zostały przez nich uporządkowane w taki właśnie sposób. Na końcu udzielono respondentom prawidłowych odpowiedzi na temat kraju pochodzenia podanych marek i zbadano ich reakcje na to, co usłyszeli.

Niemal każdy respondent wykazał się znajomością wszystkich pięciu marek wybranych do badania (fakt, że $25 \%$ - dwie osoby - z nich nie kojarzyło marek Reserved i Inglot, może wynikać z faktu, iż byli to mężczyźni, którzy w trakcie odpowiadania na pytanie podkreślali, że nie znają się na modzie i kosmetykach), mimo to pytanie, jak bardzo polska lub zagraniczna jest każda $\mathrm{z}$ marek, nie było łatwe. Spośród trzech polskich brandów występujących w badaniu Reserved uzyskało najwięcej trafnych odpowiedzi na pytanie o swoje pochodzenie. Pewność obcokrajowców nie wynikała jednak z komunikacji marki, wyglądu i stylu urządzenia sklepu, czy wreszcie jakości i cen sprzedawanych tam produktów, a z faktu, że ktoś ich o tym wcześniej poinformował. Ci z kolei, którzy nie znali pochodzenia Reserved, podświadomie stawiali na jej zagraniczne korzenie, a swoje stanowisko uzasadniali angielską nazwą oraz nowoczesnym wnętrzem sklepu, w ich ocenie mało charakterystycznym dla Polski.

W wypadku CCC praktycznie każda odpowiedź na pytanie o pochodzenie tej marki była argumentowana lokalizacją. Ci z respondentów, którzy widzieli CCC poza granicami Polski, odpowiadali, że jest to marka raczej zagraniczna. Ci zaś, którzy nie widzieli sklepów tej sieci poza Polską — że jest to marka raczej polska.

Ciekawych wniosków dostarcza analiza marki Inglot. Spośród brandów wybranych do badania, ten był najmniej kojarzony przez respondentów. Może to wynikać z samej strategii Inglota, który nie stawia na reklamę w mediach tradycyjnych, wyznając zasadę, że dobry produkt obroni i wypromuje się sam. Jeśli chodzi o kraj pochodzenia tej marki, to respondenci w swojej argumentacji sugerowali, że jej występowanie w takich krajach, jak Stany Zjednoczone czy Wielka Brytania, zmniejsza prawdopodobieństwo, iż mogłaby ona pochodzić z Polski.

Ze względu na dużą rozpoznawalność marki Zara wszyscy respondenci znali kraj jej pochodzenia (Hiszpania). W wypadku Biedronki zdania były bardziej podzielone. Ci, którzy odpowiedzieli, iż jest to marka zagraniczna, byli świadomi tego, że pochodzi z Portugalii. Argumenty badanych, którzy stawiali na to, iż może to być marka polska, odnosiły się głównie do wnętrza i wystroju sklepu - według nich prostego i mało oryginalnego, do logotypu marki, a także polsko brzmiącej nazwy.

$\mathrm{Z}$ reakcji respondentów na przedstawienie przez moderatora, które z podanych marek są w rzeczywistości polskie, można wyciągnąć wiele istotnych wniosków. Badani, którzy nie przypuszczali, że Reserved, Inglot i CCC są z Polski, byli tym faktem 
zaskoczeni. Z jednej strony komentowali, że nie spodziewali się, iż kraj taki jak Polska eksportuje również poza Europę oraz ma tak znane, międzynarodowe marki. Z drugiej strony na pytanie, czy gdyby Zara nie była marką hiszpańską, to czy mogłaby być polską, w większości odpowiadali: „tak, czemu nie, każdy kraj może mieć przecież dużą i znaną markę". Widać w tym pewien dysonans. Można podejrzewać, że obcokrajowcy mieszkający w Polsce, choć dostrzegają jej rozwój i proeuropejskość, nadal sceptycznie oceniają jej możliwości gospodarcze. Może to mieć związek z historią Polski i jej dawnym ustrojem, czy wreszcie ze stereotypami i powiązaniami Polski z krajami byłego bloku wschodniego.

Jeśli chodzi o samą kwestię komunikowania swojej polskości przez polskie marki, to jak słusznie zauważyło kilku respondentów, nadawanie polskim markom zagranicznych nazw i kreowanie międzynarodowego wizerunku wcale nie musi wynikać z faktu, że Polska jako kraj wywołuje negatywne skojarzenia (więc lepiej tego nie podkreślać w komunikacji), ale z tego, że to jedyny sposób na trafienie do większej grupy odbiorców, również tych spoza granic kraju, z którego wywodzi się dana marka. Trafnym podsumowaniem tego wątku może być wypowiedź jednego z respondentów, który tak skomentował swoje stanowisko w tej sprawie:

Polska może mieć znaną markę i jak sobie o tym myślę, to okay, ale jak faktycznie się o tym dowiaduję, że jakaś międzynarodowa marka jest z Polski, to jest to dla mnie zaskakujące... To tak jak z Chinami... jak myślisz o Chinach, to w głowie często masz tanie i kiepskiej jakości produkty, a przecież wiesz dobrze, że to potęga gospodarcza. Nie wiem, z czego to wynika... Może dlatego, że Polska jako marka jest zbyt mało charakterystyczna, mało wyrazista.

\section{Wpływ pochodzenia respondentów na udzielane odpowiedzi}

Szczegółowa analiza pokazuje, że pochodzenie respondentów ma wpływ na udzielane przez nich odpowiedzi. Obywatele Unii Europejskiej i obu Ameryk mają zdecydowanie lepsze zdanie na temat Polski i polskich marek niż nasi wschodni sąsiedzi. Są jednak kwestie, w których respondenci obu części świata są zgodni. Ze względu na podobnie sformułowane odpowiedzi, respondenci zostali podzieleni na pochodzących z państw byłego bloku wschodniego oraz pochodzących z Zachodu. Badany urodzony w Libanie został przydzielony do grupy zachodniej - jego odpowiedzi nie pokrywały się z tymi udzielonymi przez mieszkańców Ukrainy i Rosji, co może wynikać z faktu, że uczył się i studiował w jednym z krajów Europy Zachodniej.

W ocenie wizerunku Polski obie grupy badanych były zgodne co do jednej ważnej rzeczy. Słowo „Polska” nie budzi jednoznacznych skojarzeń, a jej wizerunek nie jest ani silny, ani słaby — raczej mieszany. Jeśli chodzi o różnice, to obywatele zachodniej części świata niewiele wiedzieli na temat Polski przed przyjazdem do niej, ale aktualnie dostrzegają duży potencjał zarówno ludzki, jak i gospodarczy oraz rozwój kraju. Inaczej Polska kojarzyła się i wciąż kojarzy respondentom z państw byłego bloku 
wschodniego, którzy wskazują na negatywny aspekt, jakim jest „tania siła robocza”. Podobnie w wypadku personalizacji Polski — jedyne opisy zawierające negatywne czy stereotypowe sformułowania, jakoby Polska była osobą mało wykształconą, nadużywającą alkoholu, o konserwatywnych poglądach, należą do badanych pochodzących zza naszej wschodniej granicy.

Znajomość polskich marek przez respondentów z krajów byłego bloku wschodniego oraz Zachodu jest porównywalna. Nie da się wskazać, którzy z nich mają większą świadomość i wiedzę na ten temat. Polskie produkty są przez obie grupy oceniane jako tanie i wysokiej jakości. Wyjątek stanowi tu badany ze Stanów Zjednoczonych (Zachód), dla którego polskie marki charakteryzują się raczej niską jakością. Może to wynikać z przekonania, iż gospodarka USA jest największą i najbardziej rozwiniętą na świecie. Obie grupy, z wyjątkiem respondenta pochodzącego z Libanu, zgadzają się z tym, że polskie produkty są mało ekologiczne oraz że opinia na temat tego, czy dana marka jest z Polski, nie wynika z niskiej jakości i ceny.

Zarówno mieszkańcy państw Zachodnich, jak i krajów byłego bloku wschodniego nie kryli swojego zaskoczenia, że duże marki, takie jak CCC, Reserved i Inglot, są z Polski. Różnica polegała na tym, iż respondenci ze Wschodu byli sceptycznie nastawieni do możliwości konkurowania przez Polskę z innymi krajami Europy. Obie grupy mają też inne zdanie na temat designu polskich produktów. Wszyscy badani, którzy odpowiedzieli, że jest on słaby, pochodzili z Rosji i Ukrainy. Respondenci pochodzący z zachodniej części świata ocenili go bardzo pozytywnie, co może wynikać z faktu, że Polska stara się naśladować kraje zachodnie, między innymi w projektowaniu wnętrz, produktów czy ubrań.

Przy ocenie stopnia polskości badanych marek respondenci ze Wschodu, twierdząc, że dana marka z pewnością nie jest z Polski, uzasadniali swoje stanowisko tym, iż widzieli ją także w innych krajach Europy. Oznacza to, że świadomość, iż dana marka występuje na całym świecie, zmniejsza dla naszych wschodnich sąsiadów prawdopodobieństwo jej pochodzenia z Polski. Inaczej w wypadku Zachodu. Tutaj tylko jeden badany wyraził swoje zdziwienie tym, że Inglot eksportuje do USA, to jest poza Europę. Reszty nie zaskoczył fakt, że produkty pochodzące z Polski są dostępne na całym świecie.

\section{Wnioski z badania w odniesieniu do wcześniejszych wyników}

Analiza wniosków z przeprowadzonego na obcokrajowcach mieszkających w Polsce badania potwierdza stwierdzenie zaczerpnięte z broszury informacyjnej Badania wizerunkowe ex-post Polski i polskiej gospodarki w krajach głównych partnerów gospodarczych. Polska jest zdecydowanie lepiej oceniana przez ludzi, którzy mieli kiedyś okazję ją odwiedzić. Widać to na przykładzie porównania skojarzeń ze słowem 
„Polska” towarzyszących imigrantom przed przyjazdem i po przyjeździe do naszego kraju. Uległy one znacznej poprawie.

Markami rozpoznawalnymi w 2011 roku przez respondentów badania Fundacji Best Place Europejskiego Instytutu Marketingu Miejsc były przede wszystkim tanie artykuły spożywcze i wyroby alkoholowe. $Z$ kolei wśród odpowiedzi obcokrajowców mieszkający w Polsce na pytanie o znane im polskie brandy pojawiło się kilka marek odzieżowych. Świadczy to o tym, że Polska jako kraj nie jest już kojarzona jedynie z dobrami podstawowymi, ale także z dobrami wyższego rzędu, jak ubrania.

Jak wynika z najnowszego badania SGH i ARC Rynek i Opinia z 2017 roku, polscy konsumenci uważają, że mocnymi stronami polskich produktów są cena i jakość. Na te same pozytywne aspekty wskazali obcokrajowcy mieszkający w naszym kraju. Podczas wywiadów wielokrotnie podkreślali, że w Polsce można nabyć produkty wysokiej jakości w stosunkowo niskiej cenie. Tym, co odróżnia obie grupy, jest ocena ekologiczności polskich marek. Dla Polaków polska marka to przede wszystkim ekologiczność, którą imigranci ocenili bardzo negatywnie.

\section{Wnioski i rekomendacje dla polskiej marki narodowej}

Wizerunek Polski i polskich marek w oczach obcokrajowców mieszkających w naszym kraju jest wciąż rozmyty, choć bliżej mu do pozytywnego. Różnorodność skojarzeń ze słowem „Polska”, długi czas reakcji i trudności w udzielaniu odpowiedzi na zadawane pytania są dowodem na to, że przed Polską jeszcze długa droga do stworzenia spójnej strategii marki narodowej.

Warto zwrócić uwagę na duże zmiany, jakie zaszły w postrzeganiu Polski jako kraju i które przybliżają nas do państw Europy Zachodniej. Jak wynika z badań prowadzonych na przestrzeni lat, przełom nastąpił po dołączeniu Polski do Unii Europejskiej. Od tamtej pory mieliśmy do czynienia z sekwencją zdarzeń takich, jak wybór Polaka na przewodniczącego Rady Europejskiej, organizacja Euro 2012, sportowe zwycięstwa Polaków w mistrzostwach świata w siatkówce czy złote medale na Igrzyskach Olimpijskich. Wszystko to stopniowo wpływało na wzrost zaufania do naszego kraju i jego reputację.

Przeszkodą stojącą na drodze do wykreowania silnej, polskiej marki narodowej mogą być wciąż obecne stereotypy. Dowodem na to są odpowiedzi respondentów ze Wschodu, którzy nadal kojarzą Polskę z komunizmem i tanią siłą roboczą. Obywatele Unii Europejskiej i obu Ameryk mają zdecydowanie lepsze zdanie o Polsce jako kraju. Tym, co łączy obie grupy badanych, są porównywalny poziom wiedzy i opinia na temat polskich marek - zdecydowanie za niska. Wynika to w dużej mierze z faktu, że wiele znanych polskich brandów odcina się od Polski w swoich przekazach reklamowych i szeroko pojętej komunikacji, co z kolei jest zrozumiałe dla obcokrajowców. 
Uważają oni, że w dobie globalizacji zabieg upodabniania się do marek zachodnich zwiększa szansę na sukces danego brandu.

Kraj taki jak Polska, ze skomplikowaną historią i powiązaniami z państwami byłego bloku wschodniego, jak żaden inny potrzebuje silnej marki narodowej. Tylko ciągła praca nad poprawą wizerunku może wyróżnić go spośród innych krajów postkomunistycznych, postrzeganych jako jeden „twór”7. Spójna strategia i idące za nią działania są w tym wypadku kluczem do sukcesu. Powinniśmy wykorzystać sprzyjające nam warunki, wyciągnąć wnioski z przeszłości i skupić się na wykreowaniu i umacnianiu konkretnego wizerunku Polski, jak się zdaje, współcześnie niespójnego.

\section{Image of Poland and Polish brands in the eyes of foreigners living in Poland}

\section{Summary}

The nation branding discipline, which has gained so much popularity over the last decade, aims to build a positive image of the country. The image of a country translates into its perception and treatment by the world. Ultimately, a product from a not positively associated country may be unknowingly deleted from our shopping list. The article presents the results of research conducted over the past 20 years concerning the condition of the Polish national brand. A detailed analysis of the image of Poland and Polish brands was made from the unfamiliar perspective of foreigners living in Poland. The summaries include conclusions and recommendations for building a strong national branding strategy.

7 http://www.media.uj.edu.pl/documents/1384650/134373778/Polska-e-marka-narodowa.pdf/056aed34-0d49-4933-90d1-e548c691fced (dostęp: 27 lipca 2017). 